\title{
Herding Behavior and Decision-Making within the Middle- Class Residential Property Investments
}

\author{
Sofian Arif Susanto ${ }^{*}$, Njo Anastasia ${ }^{2}$ \\ ${ }^{1}$ Civil Engineering Postgraduate, Faculty of Civil Engineering and Design, Petra Christian University, \\ Siwalankerto 121-131, Surabaya 60236, Indonesia \\ ${ }^{2}$ Finance Management Department, Faculty of Business and Economics, Petra Christian University, \\ Siwalankerto 121-131, Surabaya 60236, Indonesia \\ *Coressponding author; E-mail: 1"ian_susanto@hotmail.com; ${ }^{2}$ anas@petra.ac.id
}

\begin{abstract}
The main purpose of this study is to investigate the causality of the behavioral bias 'herding' that was traced down to both social and normative influences. An experimental method was developed to test 125 participants studying finance. The experiment provides a total of 6 houses in which the participants were instructed to appraise to a value that meets their willingness to purchase. The subjects were treated with social and normative influences and their valuation shifts were observed. In total, three valuations were recorded, labeled 'initial', 'social', and 'normative' valuations respectively. Our findings showed that the undergraduates were susceptible to both social and normative influences. However, further analysis showed that some external factors had a role in causing the herding behavior.
\end{abstract}

Keywords: Behavior; herding; social influence; normative influence; information cascade.

\section{INTRODUCTION}

Herding, known as one of the terrors that may cause the bubbles in markets leading to a financial crisis. It is also, however, an effective way of learning which is to copy another person's actions [27]. This behavior becomes a habit, and soon, humans tend to follow one another for a specific purpose at a time, regardless of the cause [30]. Knowing that there is such a behavior, countless attempts were made to better understand the market fluctuations to gain market stability [31] [32].

Traditional financial theories provide the Efficient Market Hypothesis (EMH), Expected Utility Theory (ETU), and the Prospect Theory (PT). All of the traditional theories assume that investors act rationally [21]. The three theories have been key pillars in market predictions, mainly through the perspective of utility. Over half a century the three theories were used, and by the end of the '90s, behavioral finance was a warm topic for researchers in economic instances. Escaping the rational boundary, [17] stated that desire, feelings or the level of courage also has a role in investment decisions. [18] described herding as the most discussed behavioral biases regarding investment decision-making in the real-estate stock market.

The real-estate stock market may be profitable to investors. However, in Surabaya, residential properties were considered as the most profi- table investment an individual could make [19]. Investors may consider house investments profitable since they believe land prices continue to grow, but this belief may be a potential cause to market bubbles, leading to the financial crisis. Such investors are classified into two groups, one which seeks property to gain profit, and the other for a first home purchase. [1] stated that younger individuals who purchased homes for the first time tend to be more rational in decision-making. This may be due to the consideration of such a decision as one of the biggest decision of their lives [13]. [12] suggested how individuals would the opinion of others when they have no experience in a field. This emphasizes the importance of information cascade as a possible anchor point to those who have no prior knowledge before decision-making.

There are some but little research that studied the effects of herding in the direct real estate market. [9] suggested the Perception Alignment Hypothesis (PAH) as a possible causal effect of herding through information cascade. [5] suggested an experimental method for participants to appraise residential properties to a value considered as the willingness to pay or purchase.

The experimental method considered social, normative and psychological aspects to herding. Both social and normative aspects influence a decision, whereas the psychological aspect was not due to group effects in the experiment. [8] further support the result, since personality among men 
and women around the world does not differ statistically.

This paper attempts to further study the social and normative influences in herding by modifying a previous experimental method, integrating $\mathrm{PAH}$ into it using information cascade. The remainder of the paper is organized as follows. The second section provides supporting theories and evidence on experimental design and procedures in the study. The third section reveals the results and discussion, and the fourth section concludes.

\section{Hypothesis Development}

This study is based on three key pieces of research. The first literature suggested the Perception Alignment Hypothesis (PAH), which observed the causality of herding through the use of information cascade. The second literature examined the influences of herding that was later narrowed down to social and normative influences. The third and final piece of research provided approaches to models of herding behavior across various instances and one of them classified the role of information cascade in herding.

[28] explained that information cascade was a possible cause of herding. [7] made a model assuming that all decisions made by an individual would be the same with decisions made by prior decision-makers when such information was available. [24] provided two main approaches, which consists of pattern-based approaches, and transmission-based approaches. The first focuses on physical traits, queue models, network topologies and biological flocking, such as the study of herding in flocks of birds. The other branch of herding model was separated into two categories, consisting non - mentalizing and mentalizing models. Information cascade lies within the mentalizing section of the herding model. Further utilization of the Perception Alignment Hypothesis provided three factors as a basis for information cascade, (1) credibility, (2) source of information, and (3) media of information, all of which was used as treatments in both social and normative influences.

The three factors of information cascade must be further elaborated if it is to be measured. Credibility was measured using the trust of Indonesian investors towards the source of information [23]. Trust is then measured using three indicators: (1) responsibility, (2) truthfulness, and (3) reputation [33]. [23] also stated that the source of information was to be separated into two groups, internal relations, and external relations. [11] found that 'Word of Mouth' was the most common and trusted way for Indonesians to receive information. Hence, the three indicators of PAH were used as some limitations to this study.

\section{Social and Normative Influence}

The influences that cause herding is derived from information cascade. [4] experimented on social influences on decision-making and found that individuals were susceptible to the words of others when an opinion represents $25 \%$ of the majority. Whereas, normative influence is the result of an individual's desire to fulfill the expectations of others within a group. Both influences are related to each other, as norms are derived from social interactions. The normative influence was closely related to reputational herding, which [17] stated that individuals tend to maintain their reputation. This means that they would rather fail as a group over failing by themselves. [26] further confirms this and found that investors herd in the stock market to retain their reputation. In contrast, [2] stated that investors tend to uphold their own opinions when a two-way exchange of information occurs.

\section{Valuation - Willingness to Pay, and Decision- making}

The decision-making process of house purchase can be measured by an individual's willingness to pay. The willingness of individuals who want to purchase a house requires a cognitive process, and they are closely related to the anchoring effect and loss aversion effect [5]. Furthermore, they would consider the value of the house and adjusts their judgments by experience or other information until they reach a value that is acceptable to their belief. Of course, the value regarding the house consists of a few things. Such as the objective information related to the house, including land and building area, location, or other information related to fundamental values [6]. Only when an acceptable value is reached will lead to the decision of the purchase.

\section{Herding and the Real Estate Market}

From the effects of information cascade and both the social and normative influences, decisionmakers may struggle to have multiple types of information thrown at them. An upholding of an individual's personal opinion may occur when an exchange of information occurs. However, [3] also emphasized that the acceptance of such information depends on its level of rationality to their understanding. Young families or individuals tend to be more rational than experienced investors since their motives differ from investors who seek properties only for profit. On the other hand, [16] stated that herding may be the key to the behavioral biases in depicting house price fluctuations. 


\section{The Importance of First Home Buyers}

Reports show that the Indonesian property sector has hit rock bottom in 2016 [10]. However, the young adults of Indonesia as stated in [19] were still buying and was the main buyers of residential housing in Indonesia. Demands were scarce, and would only move at a slow pace as marketing sales could only be driven by price growth. This may be due to the Indonesian people's preference to use bank loans as a primary payment method in buying houses, while the increase of subsidies in bank loans house prices increases as well, and to the extent which house prices exacerbate risks for households with bank loans but also house builders [20]

The Indonesian government then issued new regulations towards property developers to minimalize risks of foreclosure of bank loans due to the lack of buyers. Some regulations even support home purchase for those with minimum-wage laborers, such as the construction of 1 million landed residential housing across Indonesia (Program Satu Juta Rumah). Such plans may be one stepping stone towards raising the demand for residential housing in Indonesia, especially for young adults who represents the majority of residential housing purchase.

With the knowledge homeownership decline, first home buyers are essential to this predicament. Even when first home buyers need a house to live in, their income may still be relatively low, and the amount of loan approved depends on that income, hence determining the house value that can be purchased. This forces the first home buyers to be more rational compared to regular property investors, whose investment stimulus is stronger than their actual need because they have the income to spare [14] [15] [22].

To better understand herding, approaches using the Perception Alignment Hypothesis was used in a controlled investor environment. Through the use of previous experimental methods, and combining it with Perception Alignment Hypothesis, the causality of herding could be traced to both social and normative influences, hence the following hypotheses were developed.

$\mathrm{H}_{1}$ : Herding sets the difference between the final and prior valuation due to social influence.

In theory, trust was the key to how an individual may or may not regard the information given to them. This was applied to the Perception Alignment Hypothesis, and the information cascade was used to deliver information to individuals. Hence, Trust was considered and measured on how the credibility of one information may lead to herding
[15] [25]. This applies to all sorts of influences that an individual may receive, may it be either social or normative influences.

$\mathrm{H}_{2}$ : The Credibility of information moderates herding behavior in investor valuation due to social influence

Normative influence regards an individual's pride and reputation, and such events may lead to them to herd. However, when a two - way interaction (or more) is allowed between individuals, a variety of opinions and information is exchanged and the possibility to herd may decrease. Indeed, the flow of information is unrestricted among the individuals, however, this may lead to the upholding of individual opinions.

$\mathrm{H}_{3}$ : Herding sets the difference between the final and prior valuation due to normative influence

Similar to the analysis of credibility on social influence, the same process needed to be done on the normative influence treatment. This is due to both of the influences being a media for the information cascade.

$\mathrm{H}_{4}$ : The Credibility of information moderates herding behavior in investor valuation due to normative influence

\section{RESEARCH METHOD}

\section{Experiment Design}

The design of the experiment neither uses full-factorial nor partially factored experiment. Pre and Post-Experiment were used in this study to test the effects of both social and normative influences. Randomization of experiment participants was done to increase the internal validity of the experiment, by splitting the participants into groups based on their attendance. Other factors to further predict covariance was tested using analysis of covariance (ANCOVA). The main effects of both social and normative influences were tested on the valuations of residential properties.

Prior research indicated that gender groups had effects on herding [15]. In the purpose of finding the causality of herding and minimalizing errors from other variables, blocking was applied to the gender groups. The experience was another problem since previous theories suggested that it affected the decision-making process. Hence, a categorization was made from the beginning to differentiated experienced and non-experienced investors. There was no problem in the experimentation of property developers, however, the postgraduate students were non-homogenous, and 
some had already bought several properties when some have not. This predicament led to the decision to use undergraduates who were assumed to have zero experience in house purchase.

The main purpose of the experimental design was to determine the causality of herding, which lies between social and normative influences. The two influences were analyzed using ANCOVA, by testing the main effects of social and normative influences and also adding the covariates such as demography, the credibility of information to improve the internal validity of the experiment result. The model used for the first treatment can be seen in Figure 1, meaning that the initial valuation, demographic factors, and credibility of information were independent variables, whereas the socially influenced information acts as the dependent variable in this model.



Figure 1. Model for ANCOVA for Socially Influenced Valuation

During the normative induced treatment, it is apparent that participants were previously given social treatment. Norms are derived from social interactions. Thus, the socially influenced valuation was added as another variable that the third valuation depended on.

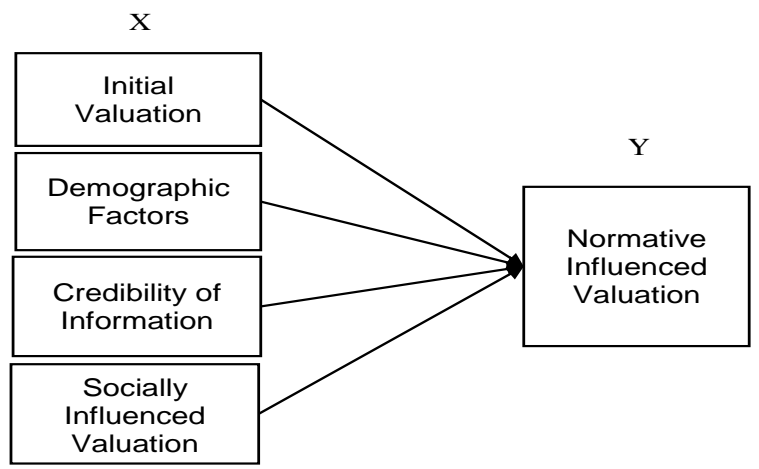

Figure 2. Model for ANCOVA for Normative Influenced Valuation

\section{Dependent Variable}

The dependent variables were the second and third valuation of the participants. The second valuation solely depends on the external flow of information which was the falsified information given to the participants (Socially Influenced Valuation). The third valuation solely depends on the internal flow of information, which occurs when the participants were allowed to discuss their valuations in groups of 4-7 people (Normative Influenced Valuation).

\section{Independent Variable}

The independent variable in this experiment was the initial valuation of the participants, it acts as the first untainted values that participants made before getting additional flows of information.

\section{Participants}

Purposive sampling was done in this research to test herding in specific groups. In this study, First Home Buyers were the main group to be studied. A pre-experiment was conducted to test how applicable the experiment method was to Indonesians. Acting as a convenient participant group, ten post-graduate students from Petra Christian University (PCU) who were studying for their master's degree were used to represent first home buyers. Ten property developers from a disclosed organization in Surabaya also participated in the pre-experiment to both the applicability of the experimental method, and testing previous theories on how experienced investors were less rational in decision-making. Only after analyzing the comments and results from the preexperiments, improvements to the method was made, and the main experiment was conducted on 125 undergraduates from PCU. The undergraduates were within the range of 18-34 years, fulfilling the first home buyer criteria. The participant demographics can be seen in Table 1 .

\section{Pre-Experiment Procedure}

The experimental process attempts to simulate the decision-making process made by the participant valuations of residential properties within the limited amount of time. The experimental instrument included two main parts, consisting of investor data and instructions for the house valuation process. The first part consists of the participant demographic data and their opinions on how credible the people were around them. The second part of the experiment was the valuation process, by giving participants a set of instructions and several brochures of houses. Details of the experimental procedure are as follows: 
Table 1. Participant Demographics

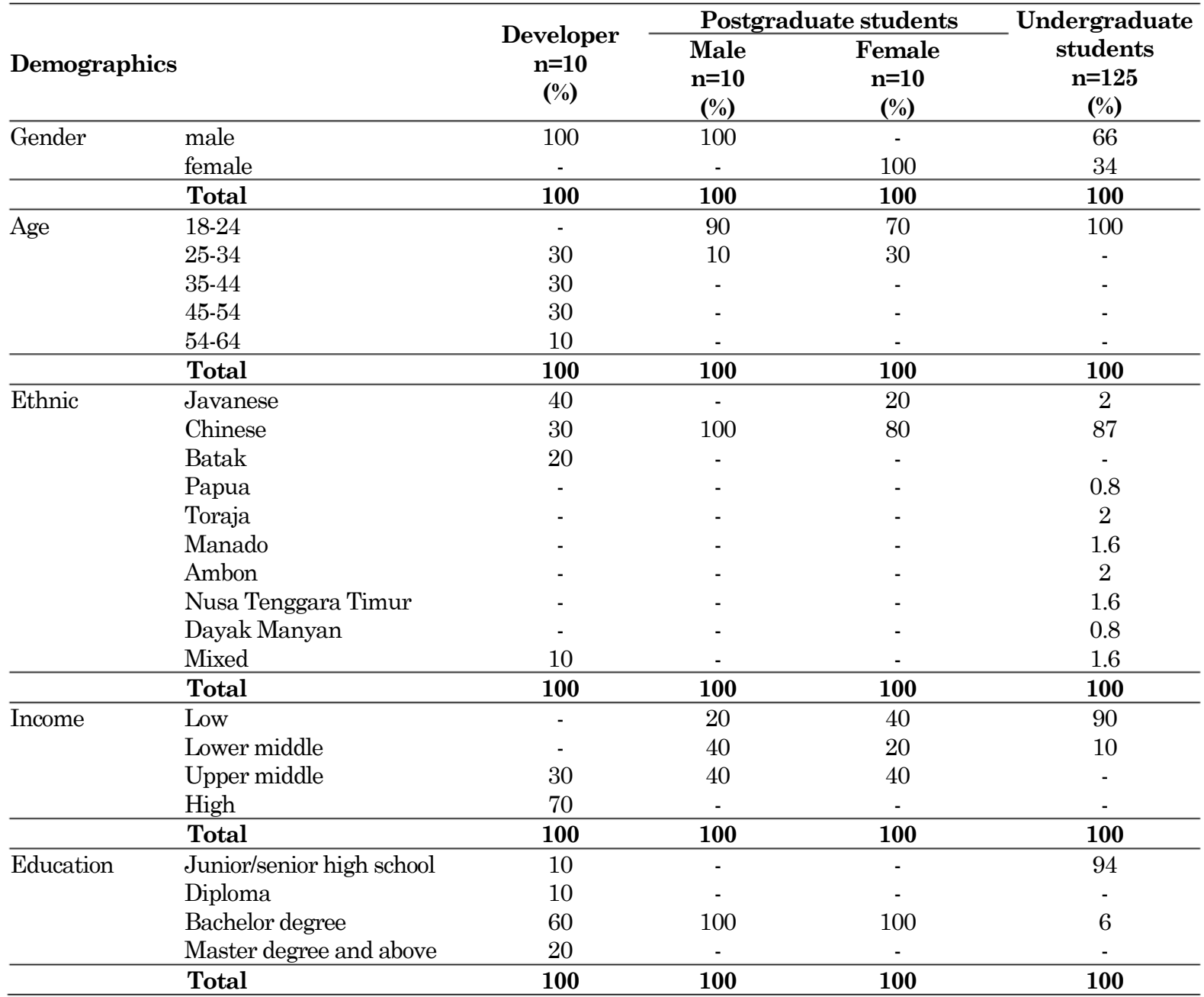

Source: Author's compilation from statistical data processing

1. Subjects were divided into groups of 5 and given 5 sets of property details for 5-real properties. The details were collected from realworld property websites. Subjects were told that all 5 properties were valued in the region of IDR 1,000,000,000. For the first two properties, the subjects were told the real-world values to give them the sense for likely valuations of the other three properties.

2. For the remaining three properties, the real values were not revealed and subjects were asked to state the initial values that they think suitable for each property.

For the second part of the experiment, subjects were given falsified information by the instructor's word of mouth. Stating values of the three remaining properties as follows: $25 \%$ of the predecessors before them valued house 1 at IDR $950,000,000,50 \%$ of the predecessors before them valued house 2 at IDR 975,000,000, and $75 \%$ of the predecessors before them valued house 3 at IDR 900,000,000. The subjects were then allowed to reconsider their valuations and given time to re-evaluate.

3. The third and final part of the experiment allows subject to communicate with each other, and subjects were then asked to place their final valuations for the three remaining houses.

\section{Pre-Experiment Results}

The data set of participant valuations were tested using non-parametric tests due to the normality of the data. Wilcoxon's method of comparing means was used to see whether the manipulation affected participant valuations. It was apparent that the participants from both property developers and post-graduate students were susceptible to both influences, and was prone to herd in some cases.

In testing both social and normative influences, the property developers herd only to social influences, which was when the opinion of others represent a majority of the crowd (75\%) with a 
Table 2. Reliability, Correlation, and Sampling Adequacy Test Results

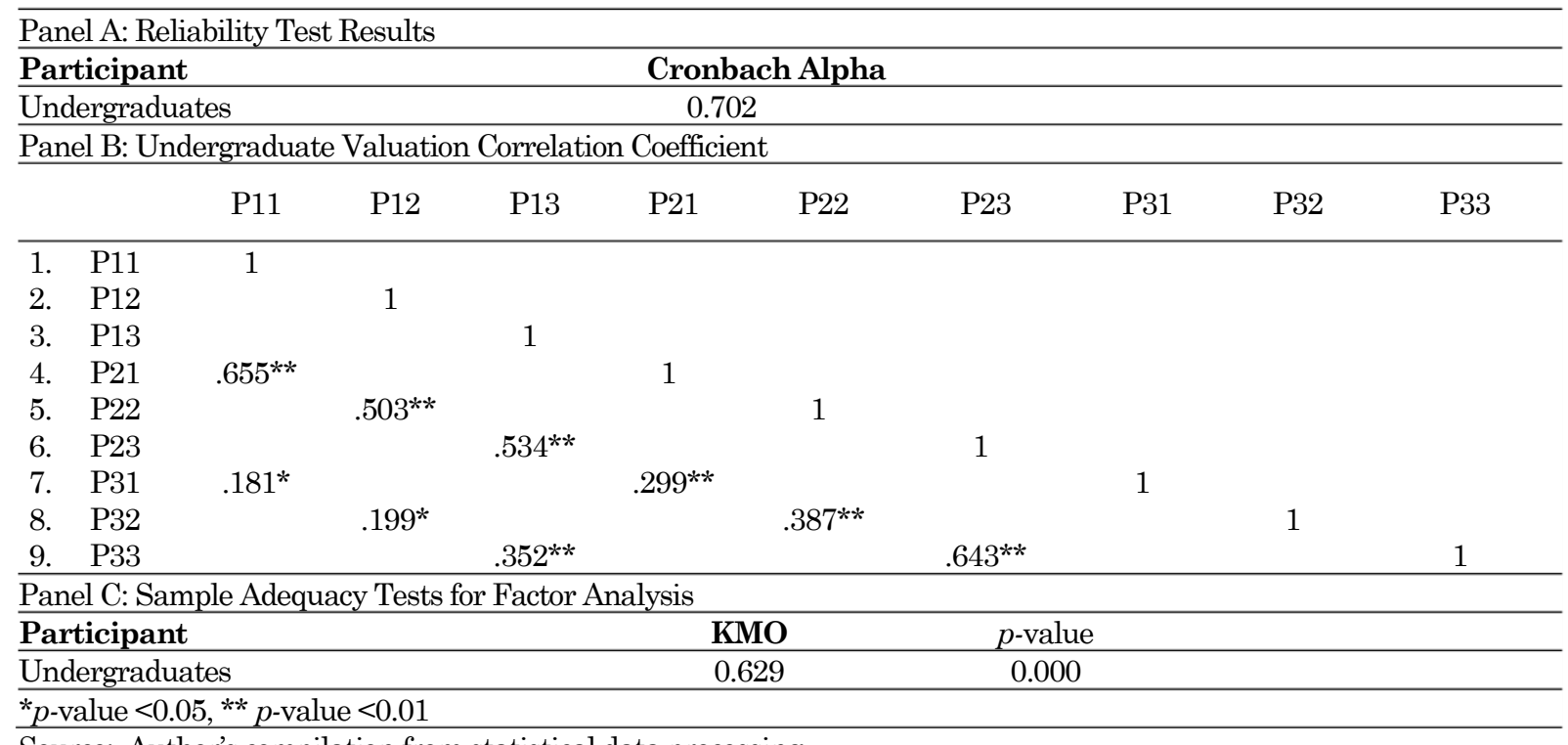

Source: Author's compilation from statistical data processing

$\mathrm{Z}$ score $=-2.375$, and $p$-value $=0.018$. The male post-graduate students succumbed to herding at all levels. Whereas, an all-female post-graduate group revealed that they were not susceptible to herding at all levels.

The checking of manipulation validates how the treatments operate, and it showed effects of the influence towards the test groups. However, some constructs were needed to be revised, such as the gender block. It now stands as a questionable variable towards the results of the valuations. In the purpose of creating a similar situation to realestate purchase, gender differentiation was removed. Time construct was also closely observed, since different times may also affect the valuation result. The time as to how long the participants had to make a valuation of the residential estates was timed to 5 minutes per session. An additional question checking on the seriousness of participants was also added, questioning who the president of Indonesia was at the current time. Another yes or no question questioning whether the participant knows the instructor beforehand was also added for further validation of the experiment results.

\section{RESULTS AND DISCUSSION}

\section{Reliability and Validation}

Reliability tests were performed to check whether the participant valuations were reliable. Correlation tests were performed to determine the interaction between the valuations and the treatment effects. A factor analysis was also done to measure the indicators from the credibility factor. Reliability and correlation tests from the valuation process and sampling adequacy test from indicators of credibility can be seen in Table 2 .

The notations that were used are as follows:

$\mathrm{P} 1_{\mathrm{i}}=$ Participant initial valuation

$\mathrm{P} 2_{\mathrm{i}}=$ Participant valuation after being induced to social influence

P3 $3_{\mathrm{i}}=$ Participant valuation after being induced to normative influence

$\mathrm{PiS}=$ Falsified property type 'i’ valuation

$\mathrm{mi}_{\mathrm{i}}=$ Credibility of information as moderator of property type 'i’

$\mathrm{i}=\mathrm{i}^{\text {th }}$ house type

The results from Table 2 showed that the data set is reliable, with the value of Cronbach alpha of 0.702 . The correlation tests also showed the relationship between the valuations which will later be used in the analysis of covariance. Bartlett's test also showed that the sample was adequate for credibility factor analysis.

\section{Hypothesis Testing}

Normality tests were also done to determine the type of test to be used on the valuation data set. It indicated that a non-parametric test method must be used, and the Wilcoxon method of comparing means was chosen. The statistical test results from the undergraduate valuations can be seen in Table 3.

The results from Table 3 showed that the second and third valuations differ from the initial valuation. However, further tests must be done to 
reveal whether the main cause of the herding behavior is due to social and normative influence alone. Aside from the main effects, further analysis of covariance was also done to test the demographic effects to the results. All demographic effects were tested except age since all participants come from the same age group. The data set was normalized and then analyzed using ANCOVA, the result can be seen in Table 4.

Table 3. Hypothesis Test on Undergraduate Valuation

\begin{tabular}{|c|c|c|c|}
\hline \multicolumn{4}{|c|}{ Panel A: Wilcoxon Test on Social Influence } \\
\hline Variable & Hypothesis & $\mathrm{Z}$ & $p$-value \\
\hline $\mathrm{P} 11-\mathrm{P} 21$ & H1 & -8.157 & $0.000 * *$ \\
\hline $\mathrm{P} 12-\mathrm{P} 22$ & $\mathrm{H} 1$ & -5.998 & $0.000 * *$ \\
\hline $\mathrm{P} 13-\mathrm{P} 23$ & H1 & -7.958 & $0.000^{* *}$ \\
\hline \multicolumn{4}{|c|}{ Panel B: Wilcoxon Test on Normative Influence } \\
\hline Variable & Hypothesis & $\mathbf{Z}$ & $p$-value \\
\hline$\overline{\mathrm{P} 11-\mathrm{P} 31}$ & H3 & -5.366 & $0.000 * *$ \\
\hline P12-P32 & H3 & -2.812 & $0.005^{* *}$ \\
\hline $\mathrm{P} 13-\mathrm{P} 33$ & H3 & -4.654 & $0.000^{* *}$ \\
\hline
\end{tabular}

Source: Author's compilation from statistical data processing ( $* *$ significant to alpha $<5 \%$ )

The results from Table 4 shows that both main effects of the initial valuations and the credibility of information affected the participant valuations on the level of $25 \%$ crowd opinion, and at most $50 \%$ of the crowd's opinion. However, the interaction effect only showed that the first home buyer's herding behavior was affected by the credibility of information at $50 \%$ of the crowd's opinion. It is to be noted that the Levene's test of homogeneity was violated on the analysis of Panel $\mathrm{B}$ and Panel $\mathrm{C}$, whereas Panel $\mathrm{A}$ had a value of $\mathrm{F}=$ 2.435 , $\mathrm{p}$-value $=.001$. On the contrary, the normative influence treatment gave results that support previous theories that suggested first home buyers be rational buyers. The analysis of covariance for the normative-treated valuations can be seen in Table 5.

The results from Table 5 showed that upon further analysis of covariance, the change from the initial valuation to the third valuation was not due to normative influence. The ANCOVA showed that we failed to reject the null hypothesis, meaning that first home buyers may herd due to other external variables that weren't included in this study. Panel B showed that the number of the purchase, as well as ethnic, affected the third valuation. However, it is to be noted that the Levene's test of homogeneity was violated in all cases.

\section{Discussion}

The first home buyers were considered as rational buyers in previous studies. The limitedtime the participants were given in appraising the residential properties should allow them to think more rationally. There was a significant change in the willingness to pay for first home buyers when treated with social and normative influences. However, the causes of herding behavior remain unclear.

The results from the socially influenced valuations showed that when at least half of a certain group has voted for the same opinion, first home buyers may follow such information. However, if it is merely a quarter, or over $75 \%$ of the crowd's opinion, first home buyers rendered the information to be unbelievable and other variables may be the cause of herding behavior. In the $25 \%$ of the crowd's opinion, education of participants was significant and it affected the valuation process. [1] stated that the first home purchase is a very important decision in an individual's life, and in its complexity, means that there will be a tendency for them to use rational systems in their decisionmaking process. Other possible explanations were the limitation of time in this experiment. In reality, the process of product selection may take a considerable amount of time before it is to be decided.

Previous studies argue that lack of experience may result in herding behavior. [29] stated that experience may affect herding, and mood may affect decision-making. This may explain the result obtained in Table 5. Panel B. Furthermore, most of the results of the proved to be insignificant, this means that there is another variable that may cause the herding behavior, such as the ethnic factor and the number of property purchase in previous events. This means that in certain ethnic groups, experience in property purchase is an important factor towards residential purchase.

\section{CONCLUSION}

This study has attempted to further investigate the causality of herding through social and normative influences, using the integration of the Perception Alignment Hypothesis. The experiment results showed that first home buyers were prone to herd, however, the causes were varied. This means that not only social and normative influence affected the herding behavior, but other factors such as education, experience, and ethnicity had a role in herding behavior.

The findings of this study were somewhat aligned with previous research, who stated that first home buyers tend to be more cognitive in decision-making. The first home buyers were prone to herd; however, the causes were varied. Social influences do have an effect on decision-making, while the normative influences do not. This means that the control of social aspects in the society and limitations in ways of communication may indirec- 
Table 4. ANCOVA findings in decision-making models of socially influenced valuations

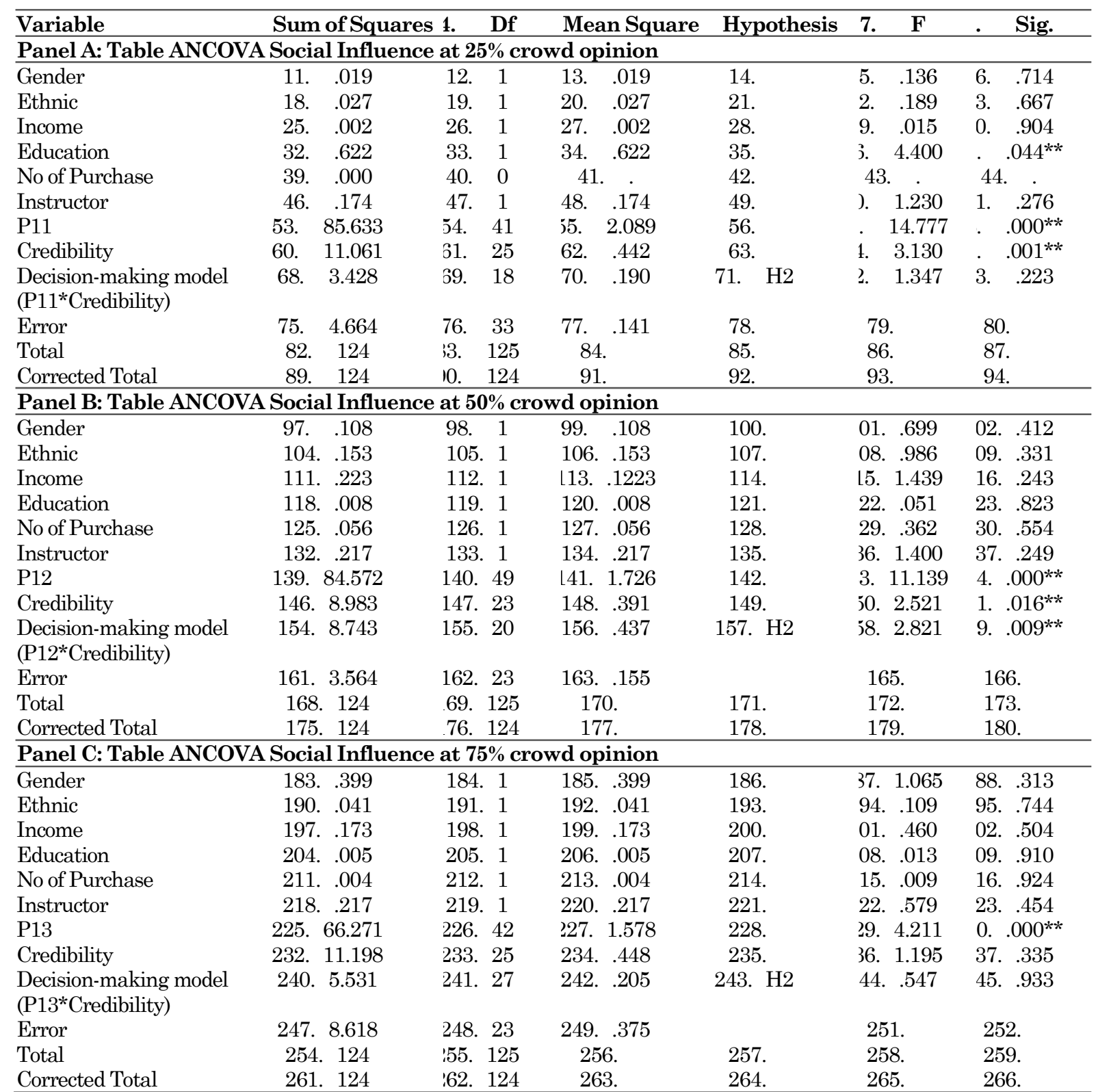

Source: Author's compilation from statistical data processing (** Significant to Alpha <5\%)

tly support the prevention of market instability. Furthermore, even when the causes of herding remain unclear, the burden remain on the local government who should create counter-intuitive plans to battle market instability. Such as the 'Program Satu Juta Rumah' home subsidy which is relatively new in Indonesia, and its effectiveness in battling market stability and homeownership decline could be studied.

Future research could attempt to improve the separation of social and normative influences. Furthermore, different subjects could also be used for comparison to first home buyers. This study was also limited by one media of communication, which was the 'Word of Mouth'. Gadgets and smartphones may be used as another tool for the information cascade in future experiments. Many internal and external variables that were practically impossible to be applied in a simulation, such as the motivation to house purchase in participants as representatives of real-world buyers.

\section{REFERENCES}

[1] Anastasia, N., Narsa, I. M. and Irwanto, A. (2018). Dual process of dual motives in real estate market Indonesia. International Journal of Housing Markets and Analysis, 12(1), 25-42. doi: https://doi.org/10.1108/IJHMA-052017-0049. 
Table 5. ANCOVA in decision-making models of normative influenced valuations

\begin{tabular}{|c|c|c|c|c|c|c|}
\hline Variable & Sum of Squ: & :71. Df & Mean Square & Hypothesis & 274. F & :75. Sig. \\
\hline \multicolumn{7}{|c|}{ Panel A: Table ANCOVA Normative Influence House I } \\
\hline Gender & 278. .387 & 279. 1 & 280. .387 & 281. & '82. .495 & !83. .487 \\
\hline Ethnic & 285. .088 & 286. 1 & 287. .088 & 288. & :89. . 112 & !90. .740 \\
\hline Income & 292. .305 & 293. 1 & 294. .305 & 295. & ‘96. . .389 & !97. .537 \\
\hline Education & 299. .402 & 300. 1 & 301. .402 & 302. & 303. .514 & i04. .479 \\
\hline No of Purchase & 306. .000 & 307. 0 & 308. . & 309. & 310. & 311. \\
\hline Instructor & 313. .430 & 314. 1 & 315. .430 & 316. & i17. .961 & i18. .464 \\
\hline P11 & 320. 38.095 & 321. 41 & 322. .929 & 323. & 24. 1.187 & i25. .310 \\
\hline Credibility & 327. 25.061 & 328. 25 & 329. 1.002 & 330. & 31. 1.281 & i32. .252 \\
\hline P21 & 334. .752 & 335. 1 & 336. .752 & 337. & 338. .961 & i39. .334 \\
\hline $\begin{array}{l}\text { Decision-making model } \\
\text { (P11*Credibility) }\end{array}$ & 342. 13.256 & 343. 18 & 344. .736 & 345. H4 & 346. .941 & i47. .542 \\
\hline Error & 349. 25.044 & 350. 32 & 351. .783 & 352. & 353. & 354. \\
\hline Total & 356. 124 & 57. 125 & 358. & 359. & 360. & 361. \\
\hline Corrected Total & 363. 124 & 64. 124 & 365. & 366. & 367. & 368. \\
\hline \multicolumn{7}{|c|}{ Panel B: Table ANCOVA Normative Influence House II } \\
\hline Gender & 371. .282 & 372. 1 & 373. .282 & 374. & 375. .427 & i76. .520 \\
\hline Ethnic & 378. 5.223 & 379. 1 & 380. 5.223 & 381. & 82. 7.895 & 33. $.010^{* *}$ \\
\hline Income & 385. .376 & 386. 1 & 387. .376 & 388. & 389. .569 & i90. .459 \\
\hline Education & 392. .001 & 393. 1 & 394. .001 & 395. & 396. .001 & i97. .977 \\
\hline No of Purchase & 399. 3.591 & 400. 1 & 101. 3.591 & 402. & 03. 5.429 & )4. $.029^{* *}$ \\
\hline Instructor & 406. .550 & 407. 1 & 408. .550 & 409. & 110. .831 & :11. .373 \\
\hline $\mathrm{P} 12$ & 413. 42.248 & 114. 49 & 415. .862 & 416. & 17. 1.303 & เ18. .253 \\
\hline Credibility & 420. 12.842 & เ21. 23 & 422. .558 & 423. & 124. .844 & เ25. .656 \\
\hline P22 & 427. .973 & 428. 1 & 429. .973 & 430. & 31. 1.471 & 32. ..238 \\
\hline $\begin{array}{l}\text { Decision-making model } \\
\text { (P12* Credibility) }\end{array}$ & 435. 23.359 & 136. 20 & 137. 1.168 & 438. H4 & 39. 1.766 & :40. .099 \\
\hline Error & 442. 14.553 & 143. 22 & 444. .661 & & 446. & 447. \\
\hline Total & 449. 124 & 50. 125 & 451. & 452. & 453. & 454. \\
\hline Corrected Total & 456. 124 & 57. 124 & 458. & 459. & 460. & 461. \\
\hline \multicolumn{7}{|c|}{ Panel C: Table ANCOVA Normative Influence House III } \\
\hline Gender & 464. .371 & 465. 1 & 466. .371 & 467. & 168. .829 & $699 . \quad .372$ \\
\hline Ethnic & 471. .684 & 472. 1 & 473. .684 & 474. & 75. 1.526 & :76. .230 \\
\hline Income & 478. .755 & 479. 1 & 480. .755 & 481. & 82. 1.685 & :83. . 208 \\
\hline Education & 485. .270 & 486. 1 & 487. .270 & 488. & 189. .602 & :90. .446 \\
\hline No of Purchase & 492. 1.273 & 493. 1 & 194. 1.273 & 495. & 96. 2.842 & 97. . 106 \\
\hline Instructor & 499. .326 & 500. 1 & 501. .326 & 502. & 503. .728 & i04. .403 \\
\hline $\mathrm{P} 13$ & 506. 20.904 & 507.42 & 508. .498 & 509. & 10. 1.111 & i11. .405 \\
\hline Credibility & 513. 11.865 & ¡14. 25 & 515. .475 & 516. & 17. 1.059 & i18. .449 \\
\hline $\mathrm{P} 23$ & 520. 1.867 & 521. 1 & 522. 1.867 & 523. & 24. 4.166 & i25. .053 \\
\hline $\begin{array}{l}\text { Decision-making model } \\
\text { (P13*Credibility) }\end{array}$ & 528. 17.960 & ¡29. 27 & 530. .665 & 531. H4 & 32. 1.485 & i33. .174 \\
\hline Error & 535. 9.857 & ¡36. 22 & 537. .448 & & 539. & 540. \\
\hline Total & 542. 124 & 43. 125 & 544. & 545. & 546. & 547. \\
\hline Corrected Total & 549. 124 & 50. 124 & 551. & 552. & 553. & 554. \\
\hline
\end{tabular}

Source: Author's compilation from statistical data processing $\left({ }^{* *}\right.$ significant at alpha $\left.<5 \%\right)$

[2] Anderson, L.R., Holt, C.A. (1996). Classroom games: information cascades. Journal of Economic Perspectives, 10(4), 187-193. doi: 10.1257/ jep.10.4.187.

[3] Anderson, L.R., Holt, C.A. (1997). Information cascades in the laboratory. The American Economic Review, 87(5), 847-862. doi: 10.2307/295 1328.

[4] Asch, S., Social Psychology, Prentice Hall., New Jersey, Englewood Cliffs, 1952.

[5] Baddeley, M. (2011). Social Influence and Household Decision - Making: A Behavioral Analysis of Household Demand. Department of Education, University of Cambridge.
[6] Baddeley, M. (2016). Housing herding: a behavioural experimental analysis. Working Paper. doi: 10.13140/RG.2.2.30188.36485.

[7] Banerjee, A.V. (1992). A simple model of herd behavior. The Quarterly Journal of Economics, 107(2), 797-817. doi: 10.2307/2118364.

[8] Cohen, Y.A., Man in Adaptation: The Cultural Present, Aldine de Gruyter., New York, 1968.

[9] Dalko, V. (2016). Perception alignment hypothesis: causality of herding? Qualitative Research in Financial Markets, 8(3), 194-204. doi: 10.1108/QRFM-01-2016-0003.

[10] DBSVI - PT. DBS Vickers Sekuritas Indonesia. (Dec 12, 2017). Indonesia industry focus, 
Indonesia property sector: Not ready to shine yet. DBS Group Research, Equity.

[11] Deloitte. (2016). Deloite Consumer Insights: The Evolution of the Indonesian Consumer. Retrieved September 20, 2017, from https:// www2.deloitte.com/content/dam/Deloitte/jp/Do cuments/consumer-business/cp/jp-cp-ci2016 idn-eng-1227.PDF.

[12] Diaz, J., Hansz, J.A. (1997). How valuers use the value opinion of others? Journal of Property investment and Investment, 15(3), 256260. doi: https://doi.org/10.1108/146357897101 84970.

[13] Dreier, P. (1982). The status of tenants in the United States. Social Problems, 30(2), 179198. doi: $10.2307 / 800517$.

[14] Goss, D. (2010). Pathways into first-homeownership. Fourth Australasian Housing. Refereed papers presented at the, Sydney, 5th- $7^{\text {th }}$ August $2009 . \quad$ https://www.be. unsw.edu.au/sites/default/files/upload/researc h/centres/cf/seminarsandconferences/2009apn hr_ahrc/papers/Goss.pdf.

[15] Hood, J.K. (1999). The determinants of home ownership: an application of human capital investment theory to the homeownership decision. Honors Projects, IL Wesleyan University, Bloomington,

71. https://digitalcommons.iwu.edu/cgi/viewconte nt.cgi?referer=https://www.google.co.id/\&https redir $=1 \&$ article=1055\&context=econ_honproj.

[16] Hott, C. (2012). The influence of herding behavior on house prices. Journal of European Real Estate Research, 5(3), 179-198. doi: 10. 1108/17539261211282046.

[17] Keynes, J.M., The General Theory of Interest, Employment and Money, Macmillan, London, 1936.

[18] Kumar, S., Goyal, N. (2015). Behavioural biases in investment decision making - a systematic literature review. Qualitative Research in Financial Markets, 7 (1), 88-108. doi: 10. 1108/QRFM-07-2014-0022.

[19] Lamudi. (2017). Laporan Industri Properti Indonesia. Retrieved October 13, 2017, from https://www.lamudi.co.id/laporan-2017.

[20] Lee, Y.T., Liu, Y.J., Roll, R. and Subrahmanyam, A. (2004). Order imbalances and market efficiency: evidence from the Taiwan stock exchange. Journal of Financial and Quantitative Analysis, 39(2), 327-341. doi: 10.1017/S0022109000003094.

[21] Malkiel, B.G. (2003). The efficient market hypothesis and its critics. Journal of Economic Perspectives, 17(1), 59-82. doi: 10.1257/089 533003321164958.
[22] Monico, M. (2013). Australian attitudes and behaviors towards buying their first home. RAMS First Home Buyers' Pulse Check Survey 2013, RAMS Financial Group, Sydney. www.rams.com.au/uploadedfiles/content/about_rams/media_centre/2013/r ams-first-home-buyerspulse-check-survey.pdf.

[23] Nielsen (2015). Word of mouth recommendations remain the most credible. Nielsen Insights. Retrieved October 19, 2017, from http://www.nielsen.com/id/en/press-room/ 2015/WORD-OF-MOUTH-RECOMMENDATIONS-REMAIN-THE-MOST-CREDIBLE. html.

[24] Raafat, R.M., Chater, N., Firth, C. (2009). Herding in humans. Trends in Cognitive Sciences, 13(10), 420-428. doi: 10.1016/j.tics.2009. 08.002 .

[25] Rofiq, A. (2007). Pengaruh dimensi kepercayaan (trust) terhadap partisipasi pelanggan e-commerce. Universitas Brawijaya. Retrieved October 19, 2017, from http://ainurrofiq.lecture.ub.ac.id/files/2012/03/tesis_ainurrofiq_di mensi_trust.pdf

[26] Scharfstein, D.S., Stein, J.C. (1990). Herd behavior and investment. The American Economic Review, 80(3), 465-479. doi: 10.2307/2006 678.

[27] Seiler, M.J., Lane, M.A., Harrison, D.M. (2014). Mimetic herding behavior and the decision to strategically default. The Journal of Real Estate Finance and Economics, 49(4), 621-653. doi: https://doi.org/10.1007/s11146012-9386-8.

[28] Shiller, R., Irrational Exuberance. Princeton, Princeton University Press., 2000.

[29] Shusha, A., and Touny, M.A. (2016). The attitudinal determinants of adopting the herd behavior: an applied study on the Egyptian exchange., Journal of Finance and Investment Analysis, 5(1), 55-69.

[30] Smith, A., The Theory of Moral Sentiments, Metalibri., Sao Paolo, 1790.

[31] Szyszka, A. (2010). Behavioral anatomy of the financial Crisis. Journal of Centrum Cathedra, 3(2), 121-135. doi: 10.7835/jcc-berj-20100042.

[32] Wang, Y. (2013). Study of herding behavior on China's real estate market price fluctuations. Information Technology Journal, 12(23), 7926-7929. doi: 10.3923/itj.2013.7926.7929.

[33] Wong, D. (2017). Pengaruh ability, benevolence dan integrity terhadap trust, serta implikasinya terhadap partisipasi pelanggan e-commerce: studi kasus pada pelanggan e commerce di UBM. Jurnal Riset Manajemen dan Bisnis FE-UNIAT, 2(2), 155-168. http:/jrmb. ejournal-feuniat.net/index.php/JRMB/article/ download/46/35. 